\title{
How Libraries were Described a Hundred and Fifty Years Ago.
}

I RECENTLY came across a work published in 1739 , and professing to be "A Critical and Historical Account of all the Celebrated Libraries in Foreign Countries, as well Ancient as Modern," which appeared to me to be of sufficient interest to the members of the Library Association to justify me in drawing their attention to it. It purports to be written "by a Gentleman of the Temple," whose identity $I$ have been unable to discover, and contains, in addition to the main subject, "General Reflections upon the Choice of Books, and the Method of furnishing Libraries," being, as its author assures us on the title-page, "A Work of great Use to all Men of Letters."

As this little book contains within the limits of 206 duodecimo pages chapters devoted to the libraries of ancient Egypt, Phœnicia, Chaldea, Ethiopia, China, Greece, Rome, and almost every country of modern Europe, it will be at once apparent that the author's treatment of his subject is comprehensive rather than exhaustive. Nevertheless, he finds space for the introduction of a good deal of curious matter which does not strictly belong to the subject, as when he considers it necessary to devote nine pages to the discussion of the question whether books and writing were. in use among the Israelites prior to the time of Moses. After this it is somewhat surprising to find that less than three pages suffice for a description "of the Libraries that have been founded since the barbarous Ages"; but on proceeding further this apparent curtailment of the narrative is corrected by a succession of chapters treating respectively of the libraries in Denmark, Holland, Germany, France, Italy, and other countries, including Turkey, with its" "Mahometan and Christian Libraries." The decorations of the Vatican Library naturally receive more attention than the books which they help to conceal, and it is comparatively satisfactory to find no less than sixteen lines devoted to the collections of the Sorbonne. 
Speaking of the King's Library at Paris, now known as the Bibliotheque Nationale, our author says: "I will not amuse the Reader with a Detail of everything singular or extraordinary in that Collection, in regard to the great Expence of Time which must be employ'd in such an Undertaking," but he gives us the information that it contains above 40,000 printed books and 10,000 manuscripts in Greek, Latin, and Arabic alone. Attached to the Library of St. Ambrose at Milan "there is a Librarian who is allow'd a Deputy, and whose Office it is to hand such Books as are wanted, and to wipe off the Dust."

This "Gentleman of the Temple" repeatedly displays his legal training by the candid and impartial manner in which he sets out the evidence on both sides of several disputed questions, leaving it to his readers, as though to a jury, to form their own opinions on the facts placed before them. But he has no hesitation in other cases in pronouncing judgment in a way' which he evidently considers to be final, as, for instance, when he comes to deal with "the Manner of placing Books in such Order, as that they may be resorted to upon any Emergency, without Difficulty, otherwise they can produce but little Advantage either to the Owners or others." Many sneers having lately been levelled at that kind of librarian who is generally known as "practical," I take some little pleasure in laying before the readers of The Library the views of a gentleman who is in no danger of falling under the somewhat mysterious stigma which that well-worn adjective is supposed to convey.

"The natural Method of placing Books and Manuscripts is," he tells us, "to range them in separate Classes or Apartments, according to the Science, Art, or Subject, of which they treat." But "as several Authors have treated of various Subjects, it may be difficult to place them under any particular Class. . . . The most adviseable Method then is, to range them under the Head of Miscellaneous Authors, with proper References to each Subject." At this point it is not quite clear whether our author is speaking of shelf-classification or of a classified catalogue ; but he goes on to render his explanation "more intelligible by an example," which I will quote in full: "Suppose, then, we would know the Names of the celebrated Historians of the Ancients; nothing more is necessary than to inspect the Class under which the Historians are placed, and so or other Faculties. By this Management, one Set of miscellaneous Authors will be sufficient, and may be resorted to with as much Ease and Expedition as those who have confined themselves to one Subject." 
I leave this elucidation to speak for itself, and will now give a few quotations from other parts of the book which seem to be illustrative of the dilettante spirit in which the office of the bookhunter was regarded in the days of the early Georges. The elementary question of what may, or may not, be considered a library is resolved by the statement that "no Collection of Books has a Right to be put into the Rank of Libraries, except it contains a great Number of Volumes, and is distributed into certain Classes, to avoid Confusion. But as it may be difficult for a private Person to have everything that is necessary to form a Library; it is sufficient for him to make a Collection of such choice Books as are in Esteem with the judicious." If I understand this deliverance rightly, it is the earliest instance I have met with of the assertion of the principle that a public library should be an universal store-house, where everything in the shape of a book may find shelter, the problems of selection being left to the solution of individuals.

When our author comes to speak of the choice of books, we learn that the libraries of Alexander Severus and Melancthon respectively contained no more than four volumes, two instances of successful compression which are supposed to illustrate the trite remark that "we must not form a Judgment of Books either by their Bulk, or Numbers, but by their intrinsic Merit and Usefulness."

Notwithstanding the hopes held out by the title-page of this curiously disappointing little work, we find the general reflections on the choice of books and the method of furnishing libraries singularly barren and devoid of anything like exact information, the author generally contenting himself with suggesting the difficulties which attend the performance of these tasks, and leaving his readers to deal with them by the light of their own wisdom. He thus sums up the main question: "In the Choice of Books Regard must be had to the Edition, Character, Paper, and Binding" Upon the first three points we get no further information, but "as to the Price, it is difficult to give any positive Directions," as it "often depends more upon the Caprice of the Buyer, than the intrinsic Merit of the Work; some piquing themselves upon the Possession of Things from no other Consideration than their exorbitant Price" It is, I suppose, unlikely that we shall ever get rid of this old complaint against the wealthy collector, and I am not at all sure that it is a real grievance to many persons, certainly not to the dealers.

In making these hasty selections during a hurried perusal of this interesting little volume, I have been animated by no desire to treat the author with disrespect, for his intentions are clearly of the best, 
Libraries Described a Hundred and Fifty Years Ago. 231

and had he lived in these days, he would doubtless have been a prominent member of The Library Association, but it seemed to me that the book was a very good illustration of the way in which libraries were regarded a hundred and fifty years ago, and that it might be worth while to compare it with the modern idea which is now becoming so familiar to us all.

In the one case, libraries are evidently regarded as being useful only to the scholar or the antiquarian, and as affording an agreeable distraction to such persons of wealth and taste as choose to become collectors, though not necessarily readers, of what the auctioneers call "literary rarities." To-day, on the other hand, it is almost universally allowed that a library (and a good one, too) is becoming more and more a necessity of existence. Those reading babits, which the spread of education and the whole tendency of modern life are doing so much to develop, have now reached a point at which they cannot longer be satisfied with such books only as a man can buy or borrow from his friends, but imperatively demand a regular supply of daily mental food, such as a large and growing library alone can provide. A library is no longer thought of as a mere collection of books, but is expected to exhibit to the critical and exacting public who use it an orderly arrangement, a good catalogue, a helpful and efficient service, and all those amenities which spring from an intelligent and capable administration.

LAWRENCE INKSTER. 